\title{
Nová česká jména bezobratlých vystavených ve stálé zoologické expozici „Vykročení všemi směry“
}

\author{
Petr Dolejš \\ Národní muzeum - Přírodovědecké muzeum, Zoologické oddělení, \\ Cirkusová 1740, 19300 Praha 9 - Horní Počernice; petr.dolejs@nm.cz
}

Dolejš P., 2021: Nová česká jména bezobratlých vystavených ve stálé zoologické expozici. - Journal of the National Museum (Prague), Natural History Series 190: 87-92.

Dne 3. září 2021 byly po deseti letech rekonstrukce a příprav otevřeny veřejnosti stálé zoologické expozice v Historické budově Národního muzea. Nové expozice kladou důraz na návštěvnický komfort cílových skupin, kterými jsou rodiny s dětmi, školní skupiny dětí a mládeže, zahraniční návštěvníci, senioři a hendikepovaní. Počítá se proto i s využitím expozic ve výuce vyšších stupňů základních a středních škol a víceletých gymnázií (Fialová et al. 2012). Expozice bezobratlých se snaží reflektovat potřeby všech těchto skupin. Základním prostředkem je proto výběr vhodných exponátů. Vystaveni jsou jednak živočichové, které návštěvník zná ze svého okolí nebo dovolené u moře, viděl je namalované v učebních či encyklopediích nebo jsou jakýmkoliv způsobem pro návštěvníka atraktivní. Dále jsou vystaveni takoví zástupci bezobratlých, aby byla představena rozmanitost a téměř všechny významné skupiny živočichů (Moravec et al. 2017). Tímto ale vyvstal drobný problém - některé vystavené druhy totiž neměly české (a někdy ani anglické) jméno. Návštěvník má ovšem přirozenou potřebu pojmenovávat předměty kolem sebe $v$ rodném jazyce a nespokojí se jen se jménem odborným, které pro něho může být obtížně vyslovitelné, nesrozumitelné a na rozdíl od národního jména si pod ním nepoučený návštěvník nic konkrétního nepředstaví (Gajdoš a kol. 2019). Navíc Národní muzeum je „tradičním“ vydavatelem

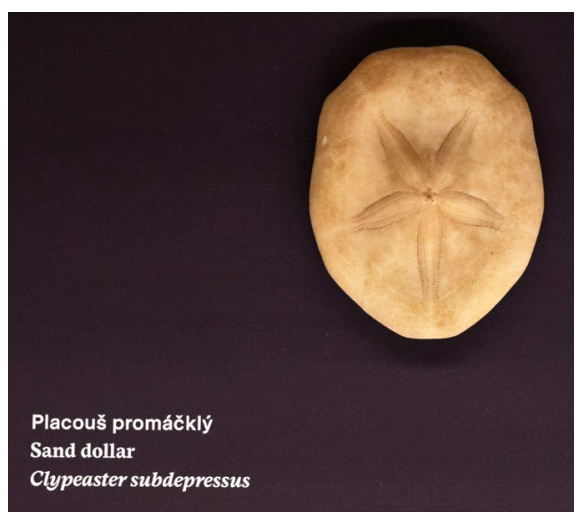

Obr. 1. Zástupce nepravidelných ježovek v nových zoologických expozicích. Foto: K. Kočí. českého názvosloví - z bezobratlých vyšlo názvosloví skupin, které nejsou dvoustranně symetrické (Pfleger 1997), měkkýšů (Pfleger 1999), pavoukovců (Kůrka \& Kovařík 2003, Kůrka 2005, 2006, 2007) a rakotvárných korýšů (Patoka et al. 2017). Proto byla těm vystaveným druhům bezobratlých, které dosud česká jména neměly, vymyšlena zcela nová česká jména. 
Aktuální vědecká (tzv. latinská) jména byla převzata $v$ případě mořských živočichů z portálu $W O R M S^{1}$, v případě sladkovodních, parazitických či suchozemských druhů pak převážně z portálu BioLib ${ }^{2}$ či on-line katalogů týkajících se daných taxonů. Anglická jména pochází z databáze WORMS, případně Wikipedia $^{3}$ či jiných internetových zdrojů. Pokud existovalo anglických jmen (tzv. common names) pro jeden druh více, bylo vybráno takové, které se v internetovém prohlížeči při současném zadání s latinským jménem vyskytovalo nejčastěji. Pakliže anglické jméno neexistovalo, živočich se $\mathrm{v}$ expozici pojmenoval existujícím jménem nejbližší vyšší skupiny (např. polychaete worm, centipede, sea urchin, sand dollar atp.), prrípadně se anglické jméno vytvořilo z latinského (napřr. Hrabě's earthworm, Hrbáček's water flea).

Coby zdroj českého názvosloví sloužily

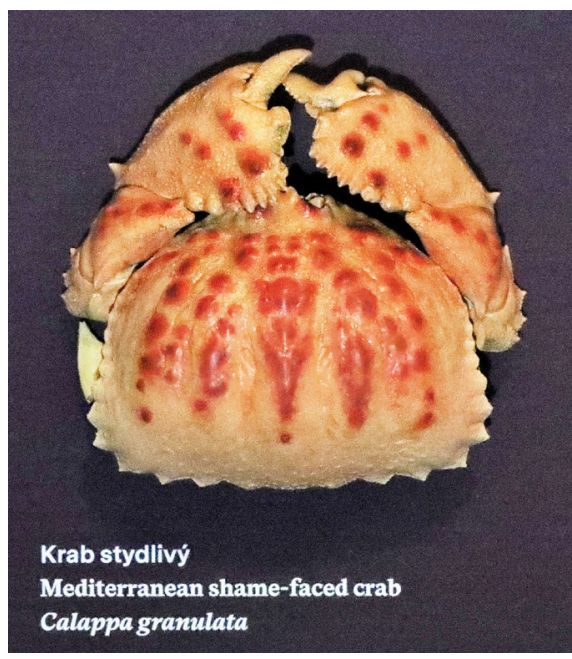

Obr. 2. Krab stydlivý instalovaný v nových expozicích. Foto: K. Kočí. odborné české publikace (např. Frič 1875, Hanzák et al. 1973, Bergbauer \& Humberg 2001, Hayward et al. 2006, Hrdličková 2012, Kolibáč et al. 2019), internetové stránky (BioLib, Př́roda.cz ${ }^{4}$ ), ale i česká jména použitá v předchozích expozicích (Pfleger et al. 1972). To je kupř. i případ dosud málo používaného rodového jména placouš pro ty nepravidelné ježovky, které se v angličtině označují „sand dollars“ (obr. 1). Pokud žádné české jméno nebylo pro daný druh ve výše uvedených zdrojích nalezeno (ani jinde na internetu při vyhledávání kombinace latinského druhového jména a českého rodového jména), bylo vytvořeno české jméno nové. To bylo odvozeno bud’ překladem vědeckého nebo anglického jména, nebo bylo vymyšleno tak, aby odráželo nějakou vlastnost toho kterého druhu (např. barvu, tvar, rozšíření, typické chování..., viz níže u jednotlivých jmen). Následně bylo opět pomocí internetových stránek ověřeno, zda již takové české jméno neexistuje, a zda tudíž nebylo vytvořené české homonymum. V některých konkrétních případech (viz níže) byla vhodnost použití českého jména konzultována s odborníky na danou skupinu. Pro potřeby nové expozice bezobratlých tak bylo vytvořeno následujících 31 českých jmen.

\section{Nová česká jména}

Kmeny a jejich vnitřní skupiny jsou řazeny systematicky, druhy v rámci skupin pak abecedně podle jejich vědeckého jména. $\mathrm{EN}$ = anglické jméno („,common name“), $\mathrm{CZ}$ = nově vytvořené české jméno.

\section{Ploštěnci (Platyhelmithes)}

Prostheceraeus giesbrechtii Lang, 1884

EN: Giesbrecht's flatworm

CZ: ploštěnka modravá (jméno reflektující převládající zbarvení)

\footnotetext{
1 http://www.marinespecies.org/

2 https://www.biolib.cz/

3 https://www.wikipedia.org/

4 https://www.priroda.cz/
} 


\section{Hlístice (Nematoda)}

Foleyella furcata Linstow, 1899

EN: chameleon filarioid

CZ: vlasovec chameleoní (jméno reflektující hostitele)

\section{Kroužkovci (Annelida)}

Allolobophora hrabei (Černosvitov, 1935)

EN: Hrabě's earthworm

CZ: žížala Hrabětova (překlad vědeckého jména odkazujícího na Sergěje Hraběte, významného českého odborníka na kroužkovce)

Hermodice carunculata (Pallas, 1766)

EN: Bearded fireworm

CZ: hermodice ohnivá (překlad anglického jména reflektující obranu druhu pomocí lámavých štětinek uvolňujících pálivou látku)

Sabella imberbis Grube, 1863

EN: -

CZ: rournatec bezvousý (překlad vědeckého jména reflektující vlastnost)

\section{Ramenonožci (Brachiopoda)}

Terebratulina septentrionalis (Couthouy, 1838)

EN: northern lamp shell

CZ: děrovka severní (překlad latinského i anglického jména reflektující převládající rozšíření)

\section{Členovci (Arthropoda)}

Armillifer grandis (Hett, 1915)

EN: visceral tongue worm

CZ: jazyčnatka západoafrická (jméno reflektující rozšíření)

Coenobita clypeatus (J. C. Fabricius, 1787)

EN: Caribbean hermit crab

CZ: poustevníček karibský (překlad anglického jména reflektující rozšíření)

Daphnia hrbaceki Juračka, Kořínek \& Petrusek, 2010

EN: Hrbáček's water flea

CZ: hrotnatka Hrbáčkova (překlad latinského jména odkazujícího na Jaroslava Hrbáčka, významného českého hydrobiologa)

Arenaeus cribrarius (Lamarck, 1818)

EN: speckled swimming crab

CZ: krab kropenatý (překlad anglického jména reflektující zbarvení)

Calappa granulata (Linnaeus, 1758)

EN: Mediterranean shame-faced crab

CZ: krab stydlivý (jméno inspirované anglickým jménem reflektujícím vzhled; obr. 2)

Carpilius corallinus (Herbst, 1783)

EN: batwing coral crab

CZ: krab korálový (překlad latinského i anglického jména reflektující zbarvení) 
Hepatus pudibundus (Herbst, 1785)

EN: flecked box crab

CZ: krab flekatý (překlad anglického jména reflektující zbarvení)

Hyas araneus (Linnaeus, 1758)

EN: great spider crab

CZ: krab pavoukový (překlad latinského i anglického jména reflektující vzhled)

Inachus dorsettensis (Pennant, 1777)

EN: scorpion spider crab

CZ: krab štíríi (překlad anglického jména reflektující vzhled)

Maguimithrax spinosissimus (Lamarck, 1818)

EN: channel clinging crab

CZ: krab bahamský (jméno reflektující rozšíření; navrženo O. Zichou)

Maja crispata Risso, 1827

EN: lesser spider crab

CZ: krab pavoučkový (jméno inspirované anglickým jménem reflektujícím vzhled)

Persephona punctata (Linnaeus, 1758)

EN: purse crab

CZ: krab měšcový (překlad anglického jména reflektující vzhled)

Pugettia producta (Randall, 1840)

EN: northern kelp crab

CZ: krab býložravý (jméno reflektující potravu)

Scolopendra subspinipes Leach, 1815

EN: -

CZ: stonoha tropická (jméno reflektující rozšíření; navrženo I. H. Tufem (2021))

\section{Ostnokožci (Echinodermata)}

Arbacia stellata (Blainville, 1825; ?Gmelin, 1791)

EN: black starry sea urchin

CZ: ježovka černohvězdá (překlad anglického jména reflektující zbarvení)

Microcyphus maculatus L. Agassiz, 1846

EN: -

CZ: ježovka flekatá (překlad latinského jména reflektující zbarvení)

Toxopneustes maculatus (Lamarck, 1816)

EN: flower urchin

CZ: ježovka jedodechá (překlad starořeckého rodového jména; obr. 3)

Clypeaster subdepressus (Gray, 1825)

EN: -

CZ: placouš promáčklý (jméno inspirované latinským jménem reflektujícím tvar; obr. 1)

Clypeaster speciosus Verrill, 1870

EN: -

CZ: placouš krásný (překlad latinského jména reflektující vlastnost)

Dendraster excentricus (Eschscholtz, 1831)

EN: eccentric sand dollar

CZ: placouš výstřední (překlad latinského i anglického jména reflektující vlastnost) 
Echinodiscus bisperforatus Leske, 1778

EN: sublitoral sand dollar

CZ: placouš pobřežní (jméno inspirované anglickým jménem reflektujícím biotop)

Hacelia attenuata Gray, 1840

EN: smooth starfish

CZ: hvězdice tvrdá (jméno reflektující vlastnost)

Linckia guildingi Gray, 1840

EN: Guilding's sea star

CZ: hvězdice Guildingova (překlad vědeckého jména odkazujícího na Lansdowna Gulidinga, specialistu na karibskou př́rodu)

Actinopyga mauritiana (Quoy \& Gaimard, 1834)

EN: surf redfish

CZ: sumýš mauricijský (překlad latinského jména reflektující rozšiření)

Pentacta doliolum (Pallas, 1766)

EN: Mauve sea cucumber

CZ: sumýš soudkovitý (překlad latinského jména reflektující tvar)

\section{Poděkování}

Za konzultaci ohledně vhodných českých názvů děkuji Ondřeji Zichovi (BioLib), Ivanu H. Tufovi (Univerzita Palackého v Olomouci), Lucii Juřičkové a Adamu Petruskovi (oba Univerzita Karlova, Praha) a Václavu Pižlovi (Biologické centrum AVČR, České Budějovice). Za kontrolu rukopisu a podnětné připomínky děkuji Petru Kmentovi a za vyfotografování vybraných exponátů pak Kateřině Kočí (oba Národní muzeum, Praha).

\section{Literatura}

Bergbauer M. \& Humberg B., 2001: Co žije ve Středozemním moři? Určovací příručka pro potápěče [Was lebt im Mittelmeer?]. - Praha: Svojtka \& Co., 319 pp. [In Czech.]

Fialová D., Junek M., Libertín M., Musil M. \& Skenář J., 2012: Nové expozice Národního muzea [New National Museum exhibits]. - Muzeum: Muzejní a vlastivědné práce 50 (Suppl.): 8199. [In Czech, with English abstract.]

Frič A., 1875: Přírodopis živočištva pro vyšší gymnasialní a realní školy [Zoology for secondary schools]. - Praha: B. Tempský, 434 pp. [In Czech.]

Gajdoš P., Černecká L'., Franc V. \& Šestáková A., 2018: Pavúky Slovenska. Slovenské názvoslovie, prehlad čel'adí a súčasné poznatky [Spiders of Slovakia. Slovak nomenclature, overview of families and present knowledge]. - Bratislava: Veda, vydavatel'stvo Slovenskej akadémie vied, 172 pp. [In Slovak.]

Hanzák J., Halík L. \& Mikulová M., 1973: Světem zvírat V. díl (1. část). Bezobratlí [World of Animals V (1). Invertebrates]. - Praha: Albatros, 324 pp. [In Czech.]

Hayward P., Nelson-Smith T. \& Shields C., 2006: Živočichové a rostliny evropského pobřeží [Sea Shore of Britain and Europe]. - Praha: Svojtka \& Co., 352 pp. [In Czech.]

Hrdličková P., 2012: Ostnokožci v učebnicích a dětských encyklopediích [Echinoderms in textbooks and encyclopedias]. - Plzeň: Západočeská univerzita v Plzni, 49 + X pp. [In Czech, with English abstract.]

Kolibáč J., Hudec K., Laštůvka Z., Peňáz M. et al., 2019: Př́roda České republiky. Průvodce faunou. Druhé, upravené a doplněné vydání [Nature of the Czech Republic. Fauna field guide. Second edition]. - Praha: Academia, 467 pp. [In Czech.]

Kůrka A., 2005: České názvy živočichů VI. Pavoukovci (Arachnida) II. Roztoči (Acari) [Czech names of animals VI. Arachnids (Arachnida) II. Mites and ticks (Acari)]. - Praha: Národní muzeum, 205 pp. [In Czech.] 
Kůrka A., 2006: České názvy živočichů VI. Pavoukovci (Arachnida) III. Sekáči (Opiliones) [Czech names of animals VI. Arachnids (Arachnida) III. Harvestmen (Opiliones)]. - Praha: Národní muzeum, 144 pp. [In Czech.]

Kůrka A., 2007: České názvy živočichů VI. Pavoukovci (Arachnida) IV. Bičovci (Amblypygi), štírenky (Palpigradi), štírci (Pseudoscorpiones), roztočovci (Ricinulei), krátkochvosti (Schizomida), solifugy (Solifugae), bičnatci (Uropygi) [Czech names of animals VI. Arachnids (Arachnida) IV. Small arachnid orders] - Praha: Národní muzeum, 126 pp. [In Czech.]

Kůrka A. \& Kovařík F., 2003: České názvy živočichů VI. Pavoukovci (Arachnida) I. Pavouci (Araneae) a štíri (Scorpiones) [Czech names of animals VI. Arachnids (Arachnida) I. Spiders (Araneae) and scorpions (Scorpiones)]. - Praha: Národní muzeum, 166 pp. [In Czech.]

Moravec J., Benda P., Dolejš P., Hájek J., Hlavaáč J., Mlíkovský J. \& Šanda R., 2017: Evoluce [Evolution]. - Muzeum: Muzejní a vlastivědná práce 55 (Suppl.): 18-23. [In Czech, with English abstract.]. https://doi.org/10.1515/mmvp-2017-0031

Patoka J., Buřič M., Bláha M., Kouba A. \& Ďuriš Z., 2017: České názvy živočichů VIII. Desetinožci (Decapoda, infrařád rakotvární (Astacidea) [Czech names of animals VIII. Decapods (Decapoda), infraorder Astacidea]. - Praha: Národní muzeum, 83 pp. [In Czech, with English abstract.]

Pfleger V., 1997: České názvy živočichů I. Houby (Porifera), žahavci (Cnidaria), žebernatky (Ctenophora) [Czech names of animals I. Sponges (Porifera), cnidarians (Cnidaria), comb jellies (Ctenophora)]. - Praha: Národní muzeum, 56 pp. [In Czech.]

Pfleger V., 1999: České názvy živočichů III. Měkkýši (Mollusca) [Czech names of animals III. Molluscs (Mollusca)]. - Praha: Národní muzeum, 108 pp. [In Czech.]

Pfleger V., Mikulová M. \& Mikula P., 1972: Bezobratlí. Katalog k expozici zoologického oddělení NM v Praze. [Invertebrata. Catalogue to exhibitions of the department of zoology, National Museum in Prague.]. - Praha: Národní muzeum, 119 pp. [In Czech, with English, German and Russian summaries.]

Tuf I. H., 2021: O nohách a reintrodukci [About legs and reintroduction]. - Vesmír 100: 360361. [In Czech.]

\section{Summary}

\section{New Czech names for the Invertebrates exposed in the permanent zoological exhibition "Stepping Out in All Directions"}

\section{Petr Dolejš}

Visitors of (not only) the National Museum often prefer for various reasons national (or common) names of the exposed animals over their scientific names. This could be a problem namely in case of the Invertebrates. Many of them lack Czech or even English common names. In order to fulfil the request of the public, 31 Czech names were created for those exposed species that had lacked national names (mostly marine crabs and echinoderms). In most cases, Czech names were derived from the English or scientific names, reflecting typical characters of the species (e.g. colour, shape, distribution, behaviour etc.). Providing Czech names of various animal groups has a long tradition in the National Museum, thus this contribution fits with long-term strategy of the institution for popularising zoology to public people.

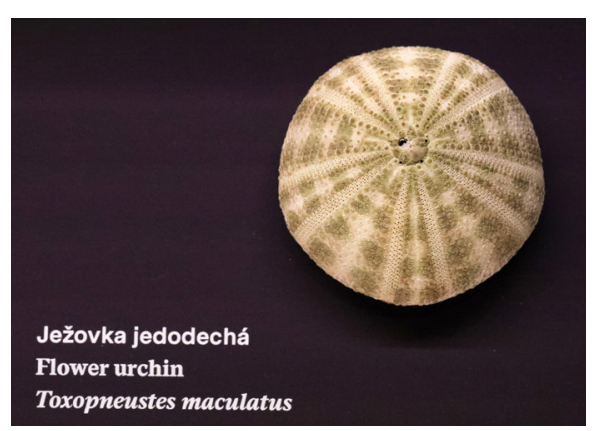

Obr. 3. Ostnokožci v nových expozicích. Foto: K. Kočí. 